TEACHING HEALTH-CARE WORKERS 


\section{TEACHING \\ HEALTH-CARE \\ WORKERS}

A Practical Guide

FRED $\underset{\text { and }}{A B B A T T}$

ROSEMARY

McMAHON

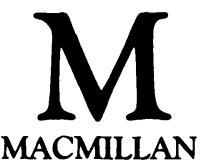


Softcover reprint of the hardcover 1st edition 1985 978-0-333-38613-2

All rights reserved. No reproduction, copy or transmission of this publication may be made without written permission.

No paragraph of this publication may be reproduced, copied or transmitted save with written permission or in accordance with the provisions of the Copyright Act 1956 (as amended).

Any person who does any unauthorised act in relation to this publication may be liable to criminal prosecution and civil claims for damages.

First published 1985

Published by

MACMILLAN EDUCATION LTD

Houndmills, Basingstoke, Hampshire RG21 2XS

and London

Companies and representatives

throughout the world

Filmsetting by Vantage Photosetting Co Ltd, Eastleigh and London

\author{
British Library Cataloguing in Publication Data \\ Abbatt, Fred \\ Teaching health-care workers. \\ 1. Community health aides. — Training of \\ I. Title II. McMahon, Rosemary 610'.7 \\ R847 \\ ISBN 978-0-333-38614-9 \\ ISBN 978-1-349-18046-2 (eBook) \\ DOI 10.1007/978-1-349-18046-2
}




\section{CONTENTS}

Foreword $\quad$ xi

How to Use this Book xiii

Acknowledgements $\quad$ xv

1 Primary Health Care: What does it Mean? 1

1.1 Origins 2

1.2 The Changed Meaning of Primary Health Care 3

1.3 The Limitations of 'Medical Care' 4

1.4 The World Health Organization and Primary Health Care 5

1.5 Primary Health Care-Definition, Principles, Strategies and Elements 6

1.6 The two Sides of the 'Health Coin'-Medical Care and Primary Health Care 9

1.7 What are the Special Features of Teaching Primary Health Care?

2 The Job of the Teacher 15

$\begin{array}{ll}2.1 & \text { What is a Teacher? } \\ & 15\end{array}$

2.2 Deciding what Students Should Learn 17

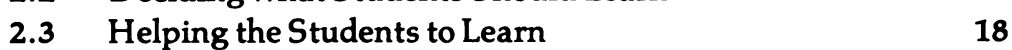

2.4 Checking that Learning has Occurred 20

2.5 Taking Responsibility for Students' Welfare 21

2.6 The Teacher as a Member of a Health Team 22

3 Deciding what should be Learnt-An Overview 27

3.1 What should be the Overall Aim of a Course? 27

3.2 What are the Consequences of Preparing Students to do a Job? $\quad 28$

3.3 Finding out about the Job 30

3.4 Writing down the Job as a List of Tasks 34

3.5 How much Detail should be Given? 35

3.6 Conclusion 36

4 How to Write a List of Tasks for a Training Course in Primary Health Care 39

4.1 Making the Draft List of Tasks for your Course 39

4.2 Improving the Draft List of Tasks by Considering Curricula, Job Descriptions and Manuals 
4.3 Improving the Task List by Comparing it with the Health Needs of the Community

4.4 Improving the Task List by Observing a Health Worker at Work

4.5 Conclusion

5 Examples of Tasks Performed by Primary Health Care Workers

5.1 Who Performs Primary Health Care Tasks?

5.2 The Tasks of the Primary Health Care Worker

5.3 The Problem-solving Process

5.4 A Classification of Problem-solving Tasks Related to Primary Health Care Elements

5.5 Examples of Tasks Related to Primary Health Care Elements

6 Task Analysis

6.1 Why is Task Analysis Useful?

6.2 What do we Mean by a Task Analysis?

6.3 How to do a Task Analysis

64

6.4 Defining Relevant and Necessary Knowledge 69

6.5 Conclusion

7 Planning the Teaching

$\begin{array}{lll}7.1 & \text { Grouping the Task List } & 73\end{array}$

$\begin{array}{lll}\mathbf{7 . 2} & \text { Planning a Course Programme } & \mathbf{7 4}\end{array}$

7.3 Why is it Important to Plan a Course Programme? $\quad 74$

7.4 How to Plan a Course Programme 75

$\begin{array}{ll}7.5 & \text { Example of a Course Programme }\end{array}$

$\begin{array}{lll}7.6 & \text { Planning a Lesson } & \mathbf{7 7}\end{array}$

7.7 Planning Practical Work and Field Visits 83

$\begin{array}{lll}7.8 & \text { Review } & 84\end{array}$

8 Planning the Assessment 87

8.1 What is Assessment? 87

8.2 Why is Assessment Necessary? 87

8.3 Some Consequences for Assessment 88

8.4 Features of Effective Assessment 90

8.5 Some Issues in Organising Assessment 92

8.6 Some Assessment Methods 94

8.7 The Objective Structured Practical Examination (OSPE) 94

9 Learning Principles and Teaching Techniques 105

9.1 Learning Principles 105

9.2 Wanting to Learn-Motivation 105

$\begin{array}{ll}9.3 \text { Social Relationships } & 107\end{array}$

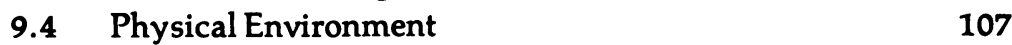


9.5 Clarity 108

9.6 Relevance to the Future 109

9.7 Relevance to Previous Experience 109

9.8 Structure 110

9.9 Active Learning 112

9.10 Feedback 113

9.11 Speed 113

9.12 Some Methods for Improving Clarity and Structure 114

9.13 Handouts and Manuals $\quad 115$

9.14 Some Methods for Encouraging Active Participation 115

10 Teaching and Assessing Knowledge 121

10.1 What do we Mean by 'Knowledge' 121

10.2 The Importance of Knowledge 122

10.3 The Functions of a Teacher in Helping Students Acquire Knowledge 123

10.4 Selecting Relevant and Necessary Knowledge 123

10.5 Establishing Sources of Information 126

10.6 Helping Students to Learn the Knowledge 128

10.7 Presenting Information Effectively 128

10.8 Helping Students to Remember Facts 132

10.9 Helping Students to Refer to Information Sources 133

10.10 Assessing Knowledge 134

10.11 Oral Examinations 135

10.12 Written Examinations 136

10.13 Open Book Examinations $\quad 140$

11 Teaching and Assessing Attitudes 143

11.1 What are Attitudes? 143

11.2 Are Attitudes Important? 144

11.3 Can Attitudes be Taught? 145

11.4 What Attitudes should be Taught? 146

11.5 Methods of Teaching Attitudes 146

11.6 Telling Students about Attitudes 147

11.7 Encouraging Students to Discuss Attitudes 148

11.8 Providing Information and Experience 149

11.9 Providing Role Models and Examples 150

11.10 Using Role-play Exercises 151

11.11 Some Examples of Role Plays 154

11.12 Assessing Attitudes $\quad 154$

12 Teaching and Assessing Communication Skills 159

12.1 What are Communication Skills? 160

12.2 The General Method of Teaching Communication Skills 163

12.3 Analysing Communication Skills 163

12.4 Describing and Demonstrating Communication Skills 164

12.5 Providing Practice in Performing Communication Skills 165

$\begin{array}{lll}12.6 & \text { Group Discussions } & 166\end{array}$ 
$\begin{array}{lll}12.7 & \text { Role Play } & 170\end{array}$

12.8 Field Experience/Interviews 172

12.9 Written Communication-Project Work 173

12.10 Assessing Communication Skills $\quad 174$

13 Teaching and Assessing Manual Skills 179

13.1 What are Manual Skills? 179

13.2 General Methods of Teaching Manual Skills 180

13.3 Deciding what Skills should be Learnt 180

13.4 Describing and Demonstrating the Manual Skill 181

13.5 Providing Initial Experience in Each Skill 182

13.6 Arranging for Further Experience 186

13.7 Assessing whether Students have Learnt the Manual Skills

14 Teaching and Assessing Decision-making Skills

14.1 What is Meant by Decision-making Skills? 199

14.2 What are the Skills of Decision Making? 201

14.3 General Methods of Teaching Decision-making Skills 202

14.4 Analysing the Decision-making Skills 202

14.5 Describing and Demonstrating the Skills to the Learner 203

14.6 Providing Practice in Decision Making 203

$\begin{array}{lll}14.7 & \text { Brain-storming } & 205\end{array}$

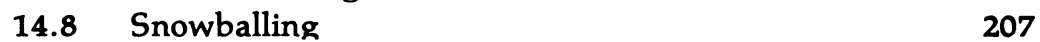

14.9 Case Histories, Case Studies and Patient-management Problems 209

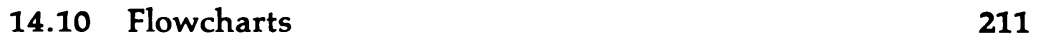

14.11 Games and Simulations $\quad 212$

14.12 Role-play Exercises 213

14.13 Observed Field Work 213

14.14 Field Work with a Supervisor $\quad 214$

14.15 Assessing Decision-making Skills 214

15 Evaluation of the Course 217

15.1 What is the Teacher's Role in Evaluation? 218

$\begin{array}{ll}15.2 & \\ 15.3 & \end{array}$

$\begin{array}{ll}15.3 & \text { How to Evaluate the Plan }\end{array}$

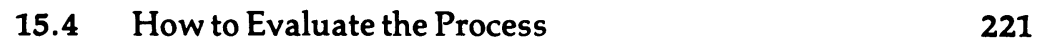

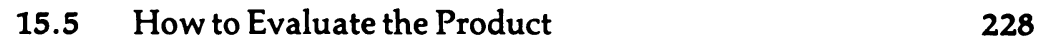

Appendix 1 Resources for Primary Health Care Teachers 231

1.A International Agencies which Supply Primary Health Care Resources $\quad 231$

1.B Selected Books and Manuals Related to Primary Health Care 
Appendix 2 Procedures

237

Appendix 3 Continuing Education

239

Appendix 4 An Example of an Assessment Scheme

243

Index 


\section{Foreword}

The concept of primary health care in the mid-1980s is very different from what it was 30 years ago. No longer primarily concerned with treating the sick, primary health care is not general practice or curative care with a few immunisations and some health teaching taken to the people. Primary health care depends on community involvement and participation, not only in carrying out the programme, but in the planning and preparation for it.

If primary health care is so different from our old concepts of medical care then we also need a very different teaching from that which is offered to, say, medical students or postgraduates. This teaching covers new and very different ground. It is also very difficult to provide as those who are taught will not just be using technologies to treat or prevent illnesses. They will be also working with the community to change the whole background in which these occur. This book is not concerned so much with teaching the actual part-time or village health worker, who so often is illiterate or semi-literate. Rather it is aiming to teach those who will be the local team-leaders of these village health workers-the medical assistants, nurses, or whatever they are called in different countries.

Fred Abbatt and Rosemary McMahon are ideally suited to write this. Few can bring so much experience. Fred Abbatt for the last 6 years has been running the highly successful course at Liverpool to train teachers of primary health care workers. Running such a course he has been in contact with such workers from around the world. He has also worked with WHO, The British Council and the UK Overseas Development Administration in many countries. This work has involved training teachers and the development of teaching programmes for health workers.

Rosemary McMahon was employed by WHO to help develop several auxiliary training programmes in Tanzania where, since independence, emphasis has been put on the training of medical assistants as the backbone of their health service. She also assisted in the development of the Rural Health series of manuals for auxiliaries published by AMREF, has worked as a consultant for World Bank funded health programmes in several countries, and has recently developed a national training programme for Community Health Officers in Sierra Leone.

This book emphasises the new knowledge and understanding of the learning process. For me it was one of the first books that I have read that has gone into, in detail, the training of the attitudes of the workers as well as detail as to how to train workers in the necessary communication skills, 
decision-making skills and knowledge to provide health care.

Introduction of the methods suggested in this book will lead to a dramatic change and, I believe, improvement in the training of all levels of paramedical workers. Perhaps this success will lead to the adoption of some of these methods in the training of medical students where perhaps the need for such training is equally as great.

Although aimed primarily at teachers in less-developed countries, there will be real value in this book to teachers in the West. Probably few books put so concisely how to develop the methods of designing course programmes, teaching the programmes and evaluating their success. Rosemary McMahon and Fred Abbatt are to be congratulated on their very real contribution to bringing in 'Health for all by 2000 '.

London, 1985

David Morley

Professor of Child Health

Institute of Child Health 


\section{How to Use this Book}

This book is a result of the authors' concern and involvement in the teaching of health-care workers in many countries. Whilst dramatic changes are taking place in the numbers of health workers trained and in the type of health care being provided, the type of training offered has not changed sufficiently. Often, the training emphasises the learning of detailed facts. The practical work and field experience may be poorly supervised and sometimes ineffective.

The aim of this book is to help teachers to rethink their whole approach to training and so to overcome these criticisms. The first two chapters describe the background of primary health care (a policy which has been adopted in nearly every country) and the role of the teacher.

Chapters 3 to 6 explain how teachers can be much more precise about what they want their students to learn. The technique of 'task analysis' is suggested which leads to clear distinctions between the different types of things which must be learnt, the knowledge and attitudes, the skills of communication and decision-making, the manual or psychomotor skills.

This definition of what needs to be learnt provides the basis for planning overall course programmes, planning the assessment of students and choosing teaching methods. These processes are described in chapters 7,8 and 9.

The teaching methods which are most appropriate for each of the five areas of learning are then described with specific examples in chapters 10 to 14 , with a final chapter on evaluating courses.

This book will not mean that teachers will be able to spend less time in teaching or that their work will be easier; rather, the authors hope that teachers will find their work more satisfying and more varied, that their students will learn more quickly and that the students will be equipped to provide a better quality of health care. 


\section{Acknowledgements}

The authors and publishers wish to thank the following who have kindly given permission for the use of copyright material:

Basil Blackwell Ltd for a graph from The Role of Medicine by Thomas McKeown.

The MEDEX Group, University of Hawaii, for an illustration from The MEDEX Primary Health Care Series: Clean Home and Clean Community.

World Health Organization for the illustration 'Visiting the Community' by J. A. Halstead from On Being in Charge: $A$ Guide for Middle-level Management in Primary Health Care by R. McMahon, E. Barton and M. Piot (WHO, 1980). 